\title{
How successful is immigrant group integration in the United States and Western Europe? A comparative review and analysis*
}

\author{
RICHARD ALBA, NANCY FONER
}

City University of New York, Graduate Center, Department of Sociology, New York, USA; e-mail: RAlba@gc.cuny.edu,nfoner@hunter.cuny.edu

ABSTRACT This article examines how successful immigrant integration is on the two sides of the Atlantic through a systematic comparison of five countries: four in Western Europe (Britain, France, Germany, and the Netherlands) and the United States. The focus is on low-status immigrant groups, such as Mexicans in the United States and Turks in Western Europe. The comparison reveals that no one country is a clear winner or loser. How successful a country is in integrating immigrants and their children depends on the institutional context or domain being examined. The analysis explores a range of domains: race and religion as well as the labor market, residence, education, mixed unions, and national identities.

KEY WORDS immigration - integration - comparative analysis - Western Europe - United States

ALBA, R., FONER, N. (2017): How successful is immigrant group integration in the United States and Western Europe? A comparative review and analysis. Geografie, 122, 4, 409-428.

Received November 2016, accepted April 2017.

(C) Česká geografická společnost, z. s., 2017

* This article is based on our semi-plenary presentation at the $13^{\text {th }}$ Annual IMISCOE Conference, Praha, July 2, 2016. We are grateful to Maurice Crul, IMISCOE Coordinator, and Dusan Drbohlav. Chair of the Conference Committee, for the invitation. The analysis draws on, and is elaborated more fully in, our book, Strangers No More: Immigration and the Challenges of Integration in North America and Western Europe (Alba, Foner 2015), which also includes Canada in the comparison. The book also explains the data used in assessing the integration of immigrants and their children in the various domains considered in this article. 


\section{Introduction}

After more than half a century of massive immigration, Western European and North American societies have been dramatically transformed by the enormous inflows that have altered the composition of their populations in significant ways and created remarkable - new - ethnic, racial, and religious diversity. A critical issue concerns the integration of immigrants and, even more, their children so that they can become full members of the societies where they now live, with, among other things, the same educational and work opportunities as the long-term native-born and acceptance and inclusion in a broad range of societal institutions.

How successful is immigrant integration on the two sides of the Atlantic? We examine this question through a systematic comparison of five countries: four in Western Europe - Britain, France, Germany, and the Netherlands, all home to large foreign-born and second generation populations and representing a range of institutional approaches to integration - and, across the ocean, the United States, the major immigrant-receiving country in North America and indeed in the world. Our focus is on immigrant groups we identify as low-status - Mexicans in the U.S., for example, and Turks in Germany - in other words, groups dominated by individuals who arrived with low levels of education, who typically ended up in low-level jobs, and are stigmatized because of their ethnicity, race, or religion. Not only are we comparing groups with similar characteristics; ${ }^{1}$ those in low-status groups also face the greatest challenges and barriers to integration.

What emerges from our comparison is that no one country is a clear winner or loser: each society fails and succeeds in different ways. Much depends on which domain or institutional context we are examining. No country is successful in every domain; nor does any country lag behind in all domains. To put it another way: how successful a country is in integrating immigrants and their children depends on the particular domain or institutional context we focus on.

Whatever the domain, our analysis highlights the crucial role of historicallyrooted social, political, and economic institutions in each receiving country that create barriers, as well as bridges, to integration and inclusion and thus are vital to understanding the patterns of integration that we found. Our analysis also makes clear that big universalizing ideas or what we call grand narratives - such as national models of integration, the settler-non-settler society distinction, U.S.

1 There is a methodological consideration in our choice of groups. Because the immigration streams to different countries vary in their composition - for example, some countries receive many high human-capital immigrants - it is important in assessing the integration capabilities of different institutional systems to compare immigrant groups that are similar in their key characteristics at the outset. Otherwise, one winds up assessing the integration of different types of immigrants rather than the impact of different institutional arrangements. 
exceptionalism, or political economy typologies between social welfare and liberal market economies - do not provide all-encompassing explanations for the successes or failures of integration in the five countries (Alba, Foner 2014).

In what follows we examine a range of domains, starting with religion and race and continuing by discussing the labor market, residence, education, mixed unions, and national identities. In conclusion, we consider the paradoxical nature of the picture that emerges, with its mix of integration, unmet challenges, and surprising advances.

\section{Religion and race}

We begin with two fundamental social divisions, religion and race, that can affect the ability of some immigrant-origin groups to eventually achieve full integration.

Religion is a domain where the United States seems more successful than Western Europe in integrating immigrants and their children, and specifically, when the issue is Islam. Listening to President Donald Trump's anti-Muslim rhetoric and reading his 2017 executive order banning visitors from several Muslim-majority countries this may seem strange to say. Indeed, there is considerable anti-Muslim sentiment in the United States, evidenced by many cases of discrimination and bias incidents, including vandalism of mosques and even occasional violence against Muslims, as well as state surveillance since the attacks of September $11^{\text {th }}$ (Bail 2014; Bakalian, Bozorgmehr 2009; Cainkar 2009; Detroit Arab American Study Team 2009).

This said, Islam has not become the same kind of divide between immigrants and natives in the United States that it has in much of Europe. As J. Cesari (2013) has put it, immigration debates have not been Islamicized or systematically connected with anti-Islamic rhetoric in the United States the way they have been in Western Europe. Also, fears that Muslims pose a threat to - indeed are undermining - core Western democratic values, such as free speech and equal rights for women and homosexuals, loom much larger in Western Europe.

In the United States, hostility to Islam has tended to be more focused on security issues and, to a large extent, on Islam as an external threat from outside the country (as Trump's executive order suggests). Of course, security issues are a component of anxieties about Muslims in Europe, especially in light of recent terrorist attacks, but there is much more emphasis there on internal threats from disaffected second-generation, European-born Muslims, including the involvement of a small, but growing number, in Islamist wars in Iraq and Syria.

There are three main reasons why Islam has become a more fundamental divide between immigrants and long-established natives in Western Europe. One is basic demographics: a much larger proportion of immigrants in Western Europe are 
Muslim (about 40 percent of those from outside the European Union), whereas in the U.S. the great majority of immigrants, about two-thirds, are Christian, and Muslims are a tiny proportion, 4-8 percent of all immigrants (Pew Forum on Religion and Public Life 2012; Mohamed 2016; Murphy 2015). Also, Muslim immigrants in Europe have a much lower socioeconomic profile in terms of poverty, unemployment, and education than those in the United States, where a substantial proportion is well educated and middle class.

Second, Western European countries are much more secular than the highly religious United States. Forms of social and cultural activity based on religious principles have less acceptance and legitimacy in Western Europe, especially when it comes to Islam, with its demands on how followers conduct their lives. Third, historically-rooted relations and arrangements between the state and religious groups in Western Europe have created greater difficulties for Muslims than in the United States, with its foundational (though often contested) constitutional principles of religious freedom and separation of church and state.

As secular as Europeans are, and although many links between church and state have been broken in the modern era, some remain; and they give special privileges to majority denominations and end up marginalizing Islam. In Germany, long-established Protestantism, Catholicism, as well as Judaism - but not Islam, the third largest religion - are recognized as public corporations entitled to federally collected church taxes and the right to run state subsidized religious services and hospitals. Government support for religious schools has created other inequalities between long-established religions and Islam. The British and French governments, for example, provide support for religious schools as long as they teach the national secular curriculum. While seemingly fair to all religions, the number of state-supported Muslim schools pales beside the large number of Protestant and Catholic ones: in Britain, to give some figures, the government funds more than 6500 Church of England and Catholic faith schools but only 27 Islamic faith schools (for a fuller discussion of religion and integration in the United States and Western Europe see Alba, Foner 2015; Foner, Alba 2008, forthcoming).

When it comes to the domain of race (and here we refer to color-coded race), the United States does not look as successful: black African ancestry creates more severe barriers for immigrants and their children than in Europe. (About one in ten immigrants in the United States is black.) This is not surprising given the sordid history of African slavery on American territory followed by legal segregation in the South (and de facto segregation elsewhere) until the mid- $20^{\text {th }}$ century.

To be sure, racial inequalities and prejudice persist in Europe, as research on African and Afro-Caribbean populations in Britain, France, and the Netherlands makes clear (e.g. Beauchemin et al. 2010, Bosma 2013, Imoagene 2017, Pilkington 2003, Solomos 2003). Yet the United States stands out for the incredibly high degree of separation of blacks and whites. Blacks in American society, whether 
immigrant or native born, continue to be highly residentially segregated from whites, a situation without parallel in western Europe. Rates of black-white intermarriage are also much lower in the United States than they are in Britain, France, and the Netherlands.

Another side to the story, however, must be noted: the special position and struggles of the large American black population have given groups of immigrant origin certain benefits that are lacking across the Atlantic. In particular, the civil rights struggles of the 1950s and 1960s led to the adoption of institutional policies and structures providing benefits that have been unavailable or less far-reaching in Europe. Perhaps most notable are affirmative action programs in universities and government employment in the United States which, despite rollbacks in recent years, expanded mobility opportunities for immigrants and the second generation seen as racial minorities, especially blacks and Latinos (e.g. Kasinitz et al. 2008). The very presence of a huge native black population with whom immigrants of color may identify, unite politically, or share organizational resources in some circumstances has also provided immigrants and their children with certain advantages that their counterparts lack in Europe

\section{Economic well-being}

Most immigrants come to the rich societies of the West with the hope of dramatically improving their economic prospects. This aspiration helps to explain the "immigrant bargain" - the initial willingness to accept low-level jobs, such as cleaning floors, in exchange for the possibility of future advances, even when immigrants arrive with educational and professional qualifications that brought significant status in their home societies. Immigrants expect to work hard but to see their economic position improve over time. Even more, many hope that their children can reach economic heights that they themselves cannot and that would have been impossible in their societies of origin.

In North America and Western Europe, the immigrant bargain seems now at risk. Changes in the economic structures of the receiving societies, growing inequality of income, and the proliferation of precarious and low-paid jobs hit immigrants and many in the second generation hard (Gautié, Schmitt 2010; Kalleberg 2009). The disadvantages of low-status immigrants loom large in both liberalmarket (Great Britain and the United States) and social-market societies (France, Germany, and the Netherlands), suggesting that these patterns are widespread and difficult to avoid (Pontusson 2005; Alba, Foner 2015).

The problem of securing stable employment is one expression of these difficulties. Immigrants typically find work during the early phases of settlement, or they would not be able or motivated to stay on. This attachment to the labor market does 
not always last. In Western Europe, immigrants are generally more likely than natives to be unemployed, and in some places their ranks include many discouraged workers who have dropped out of the labor market altogether (Heath, Chung, eds. 2007). This appears to have been the fate of many guestworkers who took jobs in declining industries; the relatively generous social-welfare nets in countries such as Germany and the Netherlands at the time allowed them to remain in Europe after they lost their footholds in the labor market (van Amersfoort, van Niekerk 2006). For those immigrants who lose their jobs in the U.S., the consummate liberal-market society, it can be difficult to remain because of its weak welfare supports and the limited access of non-citizen immigrants to them. Yet there can be positive sides to being employed, even in low-level jobs, in that employment promotes some degree of integration into the new society.

The incomes of many immigrant families are low, exposing them to economic marginality, even poverty. Average incomes tend to be lower for low-status immigrant families than for native ones, but the degree of inequality is variable, not as great in Great Britain and the Netherlands as in France, Germany, and the United States. However, the concentration of immigrant families on the very bottom tiers of the income scale is more severe than average household income data convey. For immigrants from outside the EU in the western European countries, the risk of falling to the bottom is everywhere more than 50 percent higher than it is for native families; and it is close to three times as great in France (Eurostat 2011). What seems clear is that the liberal-/social-market economy division, which is so prominent in the academic discussion, is not always relevant - or correct - for an understanding of the dynamics of labor market incorporation for low-status immigrants.

\section{Residential integration}

Immigrant neighborhoods are common sights in the cities and suburbs of rich societies. In recent years, a darker vision of these neighborhoods has taken hold. A specter haunts many native-born citizens and policymakers: the "parallel society," where immigrants and their children live isolated from the mainstream. This fear seems wildly overstated when confronted with the empirical evidence. Yet immigrant residential concentrations are apparent in all immigration societies, even though the degree of concentration and the quality of the neighborhoods vary among groups and from one national context to another.

In Western Europe, where states generally have taken a larger role in developing policies to promote the mixing of different groups and socioeconomic strata in neighborhoods, the areas of immigrant concentration are not as homogeneous as in the United States and, in many cases, include a substantial fraction of the 
native majority (Alba, Foner 2015; for European data, see, e.g., Pan Ké Shon 2011; Peach 2009; Schönwälder, Söhn 2009). In contrast to the situation in the United States, moreover, when these neighborhoods mix different immigrant groups, they typically bring together groups that speak different languages - for example Turks and Moroccans, who share some Amsterdam neighborhoods - or practice different religions, such as Hinduism and Islam in some London neighborhoods (Peach 2006). In the U.S., neighborhoods of Latino concentration are frequently ones in which a Latino majority, often composed of a mix of Spanish-speaking groups, dominates.

On both sides of the Atlantic, neighborhoods of immigrant concentration, at least for the low-status groups that are our major concern, are usually inferior to those in which the native majority typically lives. This inferiority tends to be reflected in more dilapidated and overcrowded housing, more segregated and lower quality schools, more unemployed adults (who therefore lack the connections to the labor market to help young adults find jobs), and a greater risk of criminal victimization, though the precise configuration of these conditions varies from one context to another (Alba et al. 2014). These problems are reflected in, and intensified by, the out-migration of natives, "white flight," from these areas, a pattern that has been documented in the Netherlands as in the United States.

Arguably, the disadvantages associated with residence in immigrant neighborhoods are most severe in the United States. We cannot verify this hypothesis directly because the research on neighborhood quality outside the United States is too sparse to make a well-calibrated comparison. But what make it plausible are the degree of income and wealth inequality in the United States, much higher than in other wealthy societies, and the translation of this inequality among individuals and households into inequality among neighborhoods (Reardon, Bischoff 2011). Housing and spatial location are allocated in the United States largely based on market forces - in general, one can only live where one can afford to live - and many government policies, in the form of zoning regulations, for example, tend to enhance socioeconomic distinctions among different areas. In the hierarchy of communities and neighborhoods, those at the bottom, where poor individuals and families are concentrated, tend to be very deprived by comparison with the average area. For example, research has shown that neighborhoods of Latino concentration typically are quite disadvantaged.

In principle, immigrants and their adult children can move out of heavily immigrant areas. Indeed, the negative features of these neighborhoods create an incentive to do so, as families move up economically and gain proficiency in the mainstream language. While this subject has not been investigated in depth in all of the five countries, we find evidence that this dynamic is at work in contexts as different as the Netherlands and the United States (Musterd, De Vos 2005; Sampson, Sharkey 2008). Needless to say, the possibility of mobility into better 
neighborhoods may not be available to everyone. In the United States, it is clearly not. Race is a barrier for Afro-Caribbean immigrant families and no doubt for some Latino ones. Lack of legal status impedes the mobility of many immigrant families. The degree to which equivalent barriers to mobility operate in other societies remains unknown.

Geographical mobility generally results in residential improvement, but the extent of that improvement - and of segregation from the mainstream society remains uncertain. Not enough research has been done on the residential contexts of immigrant and second-generation families living outside of immigrant concentrations. The research in the United States, by far the most extensive, indicates that Latinos make large advances in their living situations by leaving immigrant neighborhoods, but at the same time they are channeled into neighborhoods with more minorities and less affluence than those housing socioeconomically comparable whites (Alba et al. 2014; Pais, South, Crowder 2011). This picture affirms the privileged position of the native majority in the United States with respect to residence; despite the reduction in segregation associated with departure from immigrant enclaves, members of immigrant minorities do not usually attain full parity with whites.

\section{The second generation}

If wealthy societies are to benefit fully from the talents brought by recent waves of immigrants, then their schools must face up to the challenges of integrating the second generation. These challenges are especially acute for the children growing up in low-status immigrant families, in which parents often have limited educations, acquired moreover in another society, and work at low-skill jobs.

Yet overall we find that the second generations emerging from low-status immigrations - the offspring of low-wage immigrants such as Mexicans in the United States, Algerians in France, and Turks in Germany - begin their adult lives with substantial disadvantages compared to young adults who grew up in native mainstream homes. Not surprisingly, these disadvantages are manifest in the worlds of both education and work. They are of particular concern in light of the demographic transition that will occur during the next quarter century in Europe and North America, which will involve the massive exit of the baby boomers from the workforce (Alba, Foner 2015). This transition will create a need for the social mobility of many children of immigrants if the departing baby boomers are to be replaced; at the same time, of course, it will generate potential opportunities to move up for the second generation, including those from families in humble circumstances. The integration of these youth is vital for their own futures - and 
has enormous implications for the futures of the United States and the societies of Western Europe.

Granted, the children of low-status immigrants do not represent the entire second generation. Some in the second generation come from families of high human-capital immigrants, who hold university degrees and pursue highly skilled technical and professional jobs; these youth have significant advantages - and often surpass members of the native majority group in educational attainment. It is, however, the children of low-status immigrant parents who face limitations and handicaps owing to their backgrounds and who challenge the openness of the educational systems of the societies where their parents have moved and they have grown up (Alba, Holdaway, eds. 2013).

The disadvantages of students from low-status immigrant families result from a combination of factors. Their parents generally have very low levels of education by the standards of the receiving society - sometimes no formal schooling at all, like many Moroccan immigrant mothers in the Netherlands (Crul et al. 2013) - a disparity that, in turn, has a number of consequences, including an inability to provide guidance to their children in important educational decisions and assistance with homework. The children frequently grow up in homes where the immigrant, rather than mainstream, language, is used on a daily basis, and so often enter school behind other children in their proficiency in the language used there. And they stand out, and sometimes apart, in schools because they are ethnically and sometimes racially and/or religiously different from the society's majority population. This last may mean isolation from fellow students who belong to the ethno-racial majority when immigrant-origin and mainstream students attend the same school; it almost certainly implies some degree of distance from teachers.

These accumulated disadvantages mean that most immigrant-origin students need extra attention in the classroom if they are to have a chance to catch up to native majority peers. The evidence is that they do not usually receive such help - if anything, they typically receive less enriched classroom instruction. This happens in different ways in different systems. In the United States, the financing system produces quite large inequalities among schools that correspond in a rough manner with the social origins of the students they serve. Then, in secondary schools, the differences in school-taught skills channel students into different "tracks," though these are defined more informally than in many European systems. By contrast, in countries like Germany and the Netherlands, formal tracking separates students into different instruction streams at an early age - at the end of the fourth year of primary education in most German states - and thereafter they attend different schools that prepare them for different academic and labor-market destinations (Alba, Holdaway 2013; Crul, Schneider, Lelie, eds. 2012; Heath, Brinbaum, eds. 2014). 
There is an important exception to the general pattern of native-/immigrantorigin educational inequalities among the five countries that we focus on in this article. These inequalities are muted or absent in Britain, because disadvantaged groups in the immigrant generation, such as Afro-Caribbeans and Pakistanis, appear to have caught up to the native white British in terms of university credentials (even if they are less likely to earn them from the top institutions; Waters et al. 2103). This is an important development, and one for which there is as yet no persuasive explanation. T. Modood (2011) has suggested that the resources and cohesion of the communities of the Muslim groups help to explain their educational success in the second generation, and this accords with observations about the role of Asian community institutions in promoting educational achievement in the United States. (This argument does not address the Afro-Caribbean case.) However, it is also possible that the British exception is entangled with the class rigidities that operate among whites, many of whom leave school at age 16, after the GSCE examinations, to enter the labor market; these departures lower the white rate of university entrance and completion. In addition, some members of the second generation from disadvantaged groups such as the Pakistanis may persist in education in the hope that an additional credential will overcome the difficulties that they anticipate in the labor market.

The inequalities in the other four countries - France, Germany, the Netherlands, and the United States - show that no one type of system can ensure second-generation educational parity. Neither standardization nor lack of stratification per se seems to greatly reduce second-generation educational disadvantage. This said, another point needs to be underlined: extreme lack of standardization or a high level of stratification reinforces disadvantage. Highly stratified systems with early choice points - like the German - create substantial drawbacks for immigrantorigin students (Heath, Brinbaum, eds. 2014). Because of the short period that such systems give students to adjust to schooling and demonstrate their academic abilities, the systems give a great deal of weight to social origins; and their tracking, owing to such factors as the distinctiveness of the curricula on different tracks, is fateful. In addition, a very decentralized system, coupled with high levels of class and ethno-racial residential segregation - the U.S. system, in other words - has a built-in social inertia that can be difficult to overcome because of the correlation between the quality of the education students receive and their social origins.

The research on the employment and economic prospects of the contemporary second generation is more limited, but what we know is broadly consistent with the picture for educational outcomes. The second generation makes substantial advances beyond the immigrant generation. But, for most of the low-status groups, these advances still leave the second generation on average behind the native majority group. This is especially true in European societies for obtaining secure employment; in the United States, the disadvantage is not so manifest in 
the ability to get a job in the first place as it is in the quality of that job (Luthra, Waldinger 2010).

\section{Mixed unions}

Intermarriage and mixed unions are often seen as the ultimate form of integration for the second generation (this is less so for immigrants, who often have partners already when they arrive). There are striking differences within and across national contexts with respect to this type of integration. In France, to take an extreme case, the rate of mixing in partnerships goes from roughly 80 percent for second-generation southeast Asian men to under 10 percent for second-generation Turkish women (Beauchemin, Hamelle, Simon 2010). A variation of similar magnitude occurs in Britain.

Some countries feature higher mixed-partnership rates than others. In the United States, intermarriage is common, although race is a significant barrier to mixing for the children of black immigrants. The rates of marriage of U.S.-born Asians and Hispanics to partners from the white mainstream are quite a bit higher than some intermarriage rates in northern Europe, but fall short of the 50-percent mark (Qian, Lichter 2011). For Hispanics in general and for the largest group, Mexicans, the rates are 35-40 percent. For Asians in general and most Asian nationalorigin groups, the rates vary roughly between 35 and 45 percent, depending on gender (with women more likely to intermarry; Min, Kim 2010). However, only about 10 percent of the West Indian second generation has white partners.

In the four European countries, the low rates of mixed unions among secondgeneration Muslim groups stand out - with the intriguing exception of France. Given that these are sizable and highly visible immigrant-origin groups, this is especially significant. For Turks in Germany and the Netherlands, the rates for men and women of union formation with native majority partners are in the 8-15 percent range (Crul, Schneider, Lelie 2012). For Moroccans in the Netherlands, they are in the same range for women, but higher for men, at 22 percent (Central Bureau for Statistics 2013). These are, overall, low rates by any standard and indicate that the immigrant groups and the national majorities have relatively little contact with one another in family circles, even extended ones.

One reason why the lowest intermarriage rates in Europe involve Muslim groups is that a religious chasm sets them off from the secular/Christian mainstream, no doubt adding to the reluctance of potential partners on both sides. In addition, these groups have cultural traditions of marriages arranged by parents, which, needless to say, are endogamous. A key aspect of the low intermarriage rates for most major Muslim groups in Europe concerns transnational marriages, which involve importing partners from the homeland for the second generation 
(Crul, Schneider, Lelie 2012). This is not just far from intermarriage with native majority spouses - it might even be considered the diametric opposite. But secondgeneration transnational marriages take place in an environment where a partner with residential rights in a European country has value as a route to immigration; they are facilitated and encouraged by cultural traditions of arranged marriage, often with those from home villages and sometimes the extended family network, as in first cousin marriages among Pakistanis in Britain (Dale 2008).

Race - color difference - is nowhere near the barrier to partnership with the national majority in European countries that it is in the United States. In the Netherlands, the two major post-colonial groups, the Surinamese and Antilleans many of them nonwhite and Christian - are much more likely to have a partner in the Dutch majority than are Moroccans and Turks (Kalmijn, van Tubergen 2006). About half of the Surinamese do and for the Antilleans, the rates of mixed unions are startling: about 70 percent. In Britain, too, the rates of mixed partnerships (especially with white Britons) are much higher for Afro-Caribbean men and women than in the United States.

France is a key test of the influence of the national context because it shares some major Muslim populations that are numerous in Germany and the Netherlands, but like the United States, a national ideology, Republicanism, which envisions immigrants and their descendants as attaining membership in the national community and then as entitled to call themselves, and be viewed as, "French" (Schnapper 1991). The existence of such an ideology does not mean that immigrants and the second generation necessarily feel, or are accepted as, fully French. The ideology may, however, facilitate the social acceptability of those of immigrant origin in many day-to-day social situations. In fact, in France, their rates of partnership with members of the native majority are quite high. The critical cases are those of the heavily Muslim groups from North Africa, that is, Algerians, Moroccans, and Tunisians. Their rates of union with members of the native majority are at least as high as those for Asians and Hispanics in the United States, reaching to about 50 percent for young men with Moroccan or Tunisian parents. Obviously, then, not all of the Muslim groups and not all of the groups with traditions of arranged marriage are fated to have high rates of endogamy or of marriage to partners brought from the homeland.

\section{National identity}

And so we come to the issue of national identity. Being recognized as, and coming to feel like, an "insider" is a central element in the process of integration, especially for members of the second generation who, unlike their immigrant parents, were born and raised in the country where they now live. The domain of 
national identities is one where the United States is relatively successful: national identity is framed in a way that is more inclusive of immigrants and their secondgeneration children than is the case in Western Europe.

The United States is quick to extend a national identity to new immigrants and their children - to see immigrants as Americans-in-the making and regard their children as full-fledged members of the national community. Especially important is the easy acceptance of hyphenated identities as normal and unremarkable. It is acceptable - and indeed expected - for immigrants and their children to hold onto earlier ethnic identities and cultures as long as these are additions to a fundamentally American core. They are not forced to choose between an ethnic and national identity. Also - and very importantly - hyphenated identities are not something that set immigrants and their children apart. These identities are also used, at least some of the time, by Americans whose immigrant origins go generations back like Irish and Italian Americans as well as more recent Mexican Americans or Chinese Americans.

Western Europeans are less comfortable with folding newcomers into the national whole, and tend to imagine their societies as derived from a core majority population that has occupied the national territory since time immemorial. France, with its strongly assimilationist national ideology, is something of an exception; but French assimilationism is rather hostile to hybrid identities, which are common among the descendants of immigrants. In general, the second generation in Western Europe feels more pressured to express an exclusive national identity; hyphenated identities are less accepted than in the United States and in some countries lack any support at all. In France, for example, public claims to a dual national and ethnic identity are thought to weaken the sense of being French (Simon 2012). In the Netherlands, identification with another country or culture is often seen as a lack of loyalty to the Netherlands. Many in the second generation feel excluded from a Dutch identity because they are continually labeled allochthones or foreign (Slootman, Duyvendak 2015).

Part of the explanation for America's more inclusive national identity is that it is a settler society, founded and peopled by continuous flows of immigrants. As a result the practice has been to encourage immigrants to see themselves as linked to the new society as rapidly as possible. But this is too simple. Despite being an immigration society since its founding, the United States has not always been so accepting of hyphenated identities. In the early $20^{\text {th }}$ century there was a hard-edged 100 percent Americanism, with former-President Theodore Roosevelt proclaiming in 1915 that "there is no such thing as a hyphenated American who is a good American. The only man who is a good American is the man who is an American and nothing else" (quoted in Alba, Foner 2015, 204).

The key to the greater openness of an American identity to ethnic diversity today lies in two important historical developments. One was the incorporation of the 
millions of once-despised late $19^{\text {th }}$ and early $20^{\text {th }}$ century eastern and southern European immigrants and their children, which was accompanied by a refashioning of the national narrative to commemorate the United States as a nation of immigrants and the ethnic identities that grew out of immigration. The other development was the civil rights movement and legislation of the 1960s, which added momentum to the decisive move of "the discourse of integration ... beyond a singular focus on Americanization" (Bloemraad 2015) and led to acknowledging the experiences of racial minorities in national civic life and the celebration of racial and ethnic diversity. Ethnic hyphenation became, as the historian M. F. Jacobson (2006, p. 10) observes, a "natural idiom of national belonging in this nation of immigrants."

\section{Conclusion}

Everywhere one looks one finds unmet challenges with respect to the integration of low-status immigrant-origin groups. In particular, the second generations originating from low-status groups suffer what A. Heath has called "ethnic penalties" in key domains such as education and the transition to the labor market (Heath, Cheung 2007). These deficits in relation to the majority population undoubtedly have multiple sources. The children of low-status immigrants grow up in homes with limited socioeconomic resources. Their parents often are not fluent in the mainstream language, have little education (by the standards of the receiving society), and hold jobs in the bottom tiers of the labor market. These factors create large disadvantages for the children in the school system. At the same time, every such system but one (Britain, and the parity achieved there begs for a satisfactory explanation) has features that create high hurdles for students with such disadvantages - such as the low-quality schools created by the highly decentralized U.S. system, or the rigid tracking after limited exposure to the mainstream educational culture in Germany. In addition, we have no doubt that many in positions of authority in school systems and workplaces hold prejudices that lead to subtle or occasionally blatant discrimination against these second-generation youth.

In response to this picture, some might not be overly concerned. One argument could be that second generations in the past (in the U.S., for example) were in a similar position and yet integration - assimilation, really - ultimately occurred; another argument is that net of their socioeconomic origin the low-status second generations appear to be achieving what is to be expected. We want to caution against such views, which downplay the consequential nature of immigrant/ native inequalities. For one thing, the openings created by the impending demographic transition to diversity could be of limited duration, several decades at most. Moreover, given the low economic and employment growth prevailing across the wealthy countries, as well as the prospect of growing or at least 
persistent economic inequality, there could be a crystallization of the then extant ethno-racial order once the demographic transition has ended. In the countries of continental Europe, such a situation could well entail the heightening of salient social cleavages based on ethnic, racial, or religious origins. In the United States, it would involve perhaps new lines of cleavage and an augmentation of race-based cleavages that already fracture that society.

Yet an analysis that focuses only on the inequalities indicated by the average attainments of different groups risks overlooking the social and economic advances of a portion of the second generation and the broader societal changes associated with them. These phenomena are revealed by an analysis of the U.S. (Alba, Yrizar Barbosa 2016), where the ethno-racial changes taking place in the top tier of the workforce suggest the magnitude of the shifts that might be stimulated by the demographic transition to diversity, which will occur everywhere during the next several decades. In the recent past, the top tier of jobs, associated with authority and above- average remuneration, was overwhelmingly populated by the native majority, U.S.-born non-Hispanic whites. Its dominance is clearly in decline, and the retirement of the baby boomers will accelerate this process. The groups that are gaining as this decline takes place are of immigrant origin, with the gains of Asians, both foreign and native born, and of native-born Latinos the most prominent. African Americans do not appear to be benefitting as much. With respect to the opportunities for originally low-status immigrant-origin groups to move ahead because of demographic change, the gains of U.S.-born Latinos are the most noteworthy, and we add that these gains proportionately include Latinos of Mexican origin, a group about whom a great deal of concern has been expressed (e.g., Telles, Ortiz 2008).

The recent data from the U.S. reveal also some major social correlates of socioeconomic advance. The social integration of a substantial portion of the second generation is indicated by the relatively high rates of intermarriage by U.S.-born Asians and Hispanics with white Americans and the liminal position of their mixed children. The significance of intermarriage is different for the Asian and Hispanic immigrant-origin groups than it is for African Americans, who have lower rates of intermarriage overall and whose mixed-race children occupy a more problematic position in relation to the mainstream society. The adult status of the children of the numerous mixed unions of the present will be a bellwether for the evolution of ethno-racial relations in the society, as such children currently account for one in seven infants.

It seems to us reasonable to see these changes as ultimately expanding the mainstream, which can be understood here as that part of the society within which ethno-racial origins have limited effects on life chances and social interactions. Since the mainstream harbors in general the most favorable opportunities - in terms of work and living situations, say - many adult children of mixed unions will 
opt to participate in it, even if they may also preserve some attachments to their minority origins. In that respect, they may not be so different from their white ethnic predecessors, such as Italian Americans. Mixed unions are an important mechanism through which the mainstream itself will evolve and change. Where mixed couples are common, the mainstream will expand, or be remade, to take in the mixed descendants of new immigrants and possibly other minority groups and become more heterogeneous as a result (Alba, Foner 2015).

This paradoxical picture - the intergenerational persistence of inequality combined with the socioeconomic ascent and social integration of a considerable portion of immigrant-origin groups - has a number of implications for future research into the ramifications of mass immigration, for the immigrants and their children as well as for the societies that have taken them in. Among the many topics that await further study are the impact of these opposing forces and processes on Muslim immigrants and their descendants. On the one hand, the fact that a growing number of children of Muslim immigrants in Europe and the United States are moving into the middle and upper tiers of the occupational ladder and participating in mainstream political and social life is likely to increase the comfort of members of the established majority with people of Muslim background, reduce prejudice, and lead to friendships and even intermarriage. On the other hand, the prospects for high unemployment and stalled social mobility among many secondgeneration Muslims in Europe, the rising popularity of xenophobic, anti-Muslim movements and politicians there, and the possibility of future terrorist incidents by "homegrown" Muslims on both sides of the Atlantic are among the factors likely to exacerbate and intensify hostility to and discrimination against Muslims.

Further, and finally, whatever the domain of investigation, whether religion and race or residential integration and labor force participation, another issue requires more attention: the growing heterogeneity within many immigrant-origin groups. This heterogeneity has been established already for Mexican Americans by the analysis of a unique, cross-generational data set (Alba, Jiménez, Marrow et al. 2014; cf. Telles, Ortiz 2008); and the evidence we have provided here suggests the need to pay more attention to a wide range of social and economic differences, from socio-economic standing to residential context and diversity within family networks, within immigrant-origin populations. Indeed, one of the most routine research operations, comparing the averages on an indicator for different groups, is potentially misleading in the contemporary period, when some individuals from even low-status immigrant backgrounds will be able to advance socio-economically and integrate socially, even while many others from the same backgrounds will be kept on the margins of the mainstream. It will not be enough, then, to demonstrate inequalities between groups; it will be important to understand the inequalities within them, to uncover the characteristics that enable some to forge ahead while others remain excluded. 


\section{References}

ALBA, R., DEANE, G., DENTON, N., DISHA, I., MCKENZIE, B., NAPIERALA, J. (2014): The Role of Immigrant Enclaves for Latino Residential Inequalities. Journal of Ethnic and Migration Studies, 40, 1-20.

ALBA, R., FONER, N. (2015): Strangers No More: Immigration and the Challenges of Integration in North America and Western Europe. Princeton: Princeton University Press.

ALBA, R., FONER, N. (2014): Comparing Immigrant Integration in North America and Western Europe: How Much do the Grand Narratives Tell Us? International Migration Review, 48, 262-290.

ALBA, R., HOLDAWAY, J., eds. (2013): The Children of Immigrants at School: A Comparative Look at Integration in the United States and Western Europe. NYU Press, New York.

ALBA, R., JIMÉNEZ, T., MARROW, H. (2014): Mexican Americans as a Paradigm for Contemporary Intergroup Heterogeneity. Ethnic and Racial Studies, 37, 446-466.

ALBA, R., YRIZAR BARBOSA, G.I. (2016): Room at the Top? Minority Mobility and the Transition to Demographic Diversity in the U.S. Ethnic and Racial Studies, 917-938.

BAIL, C. (2014): Terrified: How Anti-Muslim Fringe Organizations Became Mainstream. Princeton University Press, Princeton.

BAKALIAN, A., BOZORGMEHR, M. (2009): Backlash 9/11: Middle Easterners and Muslim Americans Respond. University of California Press, Berkeley.

BEAUCHEMIN, C., HAMEL, C., LESNE, M., SIMON, P. (2010): Discrimination: A Question of Visible Minorities. Population and Societies, 466, 1-4.

BEAUCHEMIN, C., HAMELLE, C., SIMON, P. (2010): Trajectories and Origins: Survey on Population Diversity in France. INED and INSEE, Paris.

BLOEMRAAD, I. (2015): Re-imagining the Nation in a World of Migration: Legitimacy, Political Claims-Making and Membership in Comparative Perspective. In: Foner, N., Simon, P. (eds.): Fear, Anxiety, and National Identity: Immigration and Belonging in North America and Western Europe. Russell Sage Foundation, New York.

BOSMA, U., ed. (2013): Post-Colonial Immigrants and Identity Formations in the Netherlands. Amsterdam University Press, Amsterdam.

CAINKAR, L. (2009): Homeland Insecurity: The Arab American and Muslim American Experience after 9/11. Russell Sage Foundation, New York.

Central Bureau for Statistics (2013): Huishoudens naar herkomstgroepering, http://statline.cbs. $\mathrm{nl} /$ StatWeb/publication/ (6.1.2016).

CESARI, J. (2013): Why the West Fears Islam. Palgrave Macmillan, New York.

CRUL, M., HOLDAWAY, J., DE VALK, H., FUENTES, N., ZAAL, M. (2013): Educating the Children of Immigrants in Old and New Amsterdam. In: Alba, R., Holdaway, J. (eds.): The Children of Immigrants at School: A Comparative Look at Integration in the United States and Western Europe. NYU Press, New York.

CRUL, M., SCHNEIDER, J., LELIE, F., eds. (2012): The European Second Generation Compared: Does the Integration Context Matter? University of Amsterdam Press, Amsterdam.

DALE, A. (2008): Marriage, Migration and Employment amongst Indian, Pakistani and Bangladeshi Residents in the UK. CCSR Working Paper 2008-02, University of Manchester.

Detroit Arab American Study Team (2009): Citizenship and Crisis: Arab Detroit after 9/11. New York: Russell Sage Foundation.

EUROSTAT (2011): Migrants in Europe: A Statistical Portrait of the First and Second Generation, 2011 edition. EU, Luxembourg. 
FONER, N., ALBA, R. (2008): Immigrant Religion in the U.S. and Western Europe: Bridge or Barrier to Inclusion? International Migration Review, 42, 360-392.

FONER, N., ALBA, R. (forthcoming): Being Muslim in the United States and Western Europe: Why is it Different? In: Bozorgmehr, M., Kasinitz, P. (eds.): Growing Up Muslim in Europe and the United States. Routledge, New York.

GAUTIÉ, J., SCHMITT, J. (2010): Low-Wage Work in the Wealthy World. Russell Sage Foundation, New York.

HEATH, A., BRINBAUM, Y., eds. (2014): Unequal Attainments: Ethnic Educational Inequalities in Ten Western Countries. Proceedings of the British Academy 196. Oxford University Press for the British Academy, Oxford.

HEATH, A., CHEUNG, S.Y., eds. (2007): Unequal Chances: Ethnic Minorities in Western Labor Markets. Proceedings of the British Academy. Oxford University Press for the British Academy, Oxford.

IMOAGENE, O. (2017): Beyond Expectations: Second Generation Nigerians in the United States and Britain. University of California Press, Berkeley.

JACOBSON, M.F. (2006): Roots, Too: White Ethnic Revival in Post-Civil Rights America. Harvard University Press, Cambridge.

KALLEBERG, A. (2009): Precarious Work, Insecure Workers: Employment Relations in Transition. American Sociological Review, 74, February, 1-22.

KALMIJN, M., VAN TUBERGEN, F. (2006): Ethnic Intermarriages in the Netherlands: Confirmations and Refutations of Accepted Insights. European Journal of Population, 22, 371-397.

KASINITZ, P., MOLLENKOPF, J., WATERS, M.C., HOLDAWAY, J. (2008): Inheriting the City: The Children of Immigrants Come of Age. Russell Sage Foundation and Harvard University Press. New York and Cambridge, Mass.

LUTHRA, R.R., WALDINGER, R. (2010): Into the Mainstream? Labor Market Outcomes of Mexican-Origin Workers. International Migration Review, 44, Winter, 830-868.

MIN, P.G., KIM, C. (2010): Patterns of Intermarriages and Cross-Generational In-Marriages among Native-Born Asian Americans. International Migration Review, 43, 443-470.

MODOOD, T. (2011): Capitals, Ethnic Identity, and Educational Qualifications. In: Alba, R., Waters, M. (eds.): The Next Generation: Immigrant Youth in Comparative Perspective. NYU Press, New York.

MOHAMED, B. (2016): A new estimate of the U.S. Muslim population. Pew Research Center Fact Tank, www.pewresearch.org/fact-tank/2016/01/06/a-new-estimate-of-the-u-s-muslimpopulation (6.1.2016).

MURPHY, C. (2015): Growing Share of U.S. Immigrants Have No Religious Affiliation. Pew Research Center, Washington, D.C., May 19.

MUSTERD, S., DE VOS, S. (2005): Residential Dynamics in Ethnic Concentrations. Housing Studies, 22, 333-353.

PAIS, J., SOUTH, S., CROWDER, K. (2011): Metropolitan Heterogeneity and Minority Neighborhood Attainment: Spatial Assimilation or Place Stratification? Social Problems, 59, 2, 259-281.

PAN KE SHON, J.-L. (2011): La ségrégation des immigrés en France: état des lieux. Population \& Sociétés, 477, April.

PEACH, C. (2006): Islam, Ethnicity and South Asian Religions in the London 2001 Census. Transactions of the Institute of British Geographers, 31, 353-370.

PEACH, C. (2009): Slippery Segregation: Discovering or Manufacturing Ghettos? Journal of Ethnic and Migration Studies, 35, 138-195. 
Pew Forum on Religion and Public Life (2012): Faith on the Move: The Religious Affiliation of International Migrants. Pew Research Center, Washington, D.C.

PILKINGTON, A. (2003): Racial Disadvantage and Ethnic Diversity in Britain. Palgrave Macmillan, Houndmills, England.

PONTUSSON, J. (2005): Inequality and Prosperity: Social Europe vs. Liberal America. Cornell University Press, Ithaca.

QIAN, Z., LICHTER, D. (2011): Changing Patterns of Interracial Marriage in a Multiracial Society. Journal of Marriage and Family, 73, 1065-1084.

REARDON, S., BISCHOFF, K. (2011): Income Inequality and Income Segregation. American Journal of Sociology, 116, 1092-1153.

SAMPSON, R., SHARKEY, P. (2008): Neighborhood Selection and the Social Reproduction of Concentrated Racial Inequality. Demography, 45, 1-29.

SCHNAPPER, D. (1991): La France de l'intégration: Sociologie de la nation en 1990. Éditions Gallimard, Paris.

SCHÖNWÄLDER, K., SÖHN, J. (2009): Immigrant Settlement Structures in Germany: General Patterns and Urban Levels of Concentration of Major Groups. Urban Studies, 46, 1439-1460.

SIMON, P. (2012): French National Identity and Integration: Who Belongs to the National Community? Migration Policy Institute, Washington, D.C.

SLOOTMAN, M., DUYVENDAK, J.W. (2015): Feeling Dutch: The Culturalization and Emotionalization of Citizenship and Second Generation Belonging in the Netherlands. In: Foner, N., Simon, P. (eds.): Fear, Anxiety, and National Identity: Immigration and Belonging in North America and Western Europe. Russell Sage Foundation, New York.

SOLOMOS, J. (2003): Race and Racism in Britain. Third Edition. Palgrave Macmillan, Houndmills, England.

TELLES, E., ORTIZ, V. (2008): Generations of Exclusion: Mexican Americans, Assimilation, and Race. Russell Sage, New York.

VAN AMERSFOORT, H., VAN NIEKERK, M. (2006): Immigration as a Colonial Inheritance: Post-Colonial Immigrants in the Netherlands, 1945-2002. Journal of Ethnic and Migration Studies, 32, April, 323-346.

WATERS, M.C., HEATH, A., TRAN, V., BOLIVER, V. (2013): The Educational Careers of the Children of Immigrants in Britain and the U.S. In: Alba, R., Holdaway, J. (eds.): The Children of Immigrants at School: A Comparative Look at Integration in the United States and Western Europe. NYU Press, New York.

\section{SHRNUTí}

\section{Jak úspěšná je skupinová integrace imigrantů ve Spojených státech amerických a v západní Evropě? Komparativní přehled a rozbor}

Po rozsáhlém přistěhovalectví, trvajícím déle než půl století, byly společnosti v západní Evropě a Severní Americe přeměněny obrovskými přívaly obyvatel, jež měly počátek v padesátých letech minulého století. Podstatně změnily složení tamějšího obyvatelstva a vytvořily pozoruhodnou, často novou národnostní, rasovou a náboženskou rozmanitost. Tématem článku je integrace přistěhovalců a zejména jejich dětí, aby se mohly stát plnohodnotnými členy společností, v nichž 
nyní žijí. To zahrnuje mimo jiné rovné př́ležitosti při vzdělávání a práci jako u starousedlíků a přijetí a začlenění do širokého spektra společenských institucí.

Článek zkoumá, jak úspěšná je integrace přistěhovalců po obou březích Atlantiku systémovým srovnáváním pěti zemí. Jednak jsou to čtyři země v západní Evropě (Spojené království, Francie, Německo a Nizozemsko), jež jsou vesměs domovem početné populace narozené v cizině a její druhé generace a které zastupují pestrou paletu institucionálního přístupu k integraci, a dále za oceánem Spojené státy americké, což je ve světě ústřední země přijímající přistěhovalce. Článek se zaměřuje na přistěhovalecké skupiny s nízkým společenským postavením, jako jsou např́íklad Mexičané v USA a Turci v západní Evropě. To znamená skupiny, v nichž převažují jedinci, kteří přišli s nízkou úrovní vzdělání a zpravidla zůstali u druhořadých zaměstnáních a jsou v důsledku své národnosti, rasy nebo náboženství stigmatizováni. Tyto skupiny mají podobné charakteristiky a při integraci často narážejí na největší obtíže a překážky.

Srovnání zjištuje, že nelze žádnou zemi označit za jasného vítěze, ale ani poraženého: každá společnost si v té či oné sféře připisuje nezdary, ale i úspěchy. Leccos závisí na dané oblasti nebo institucionálním kontextu, který je předmětem výzkumu. Žádná země neuspěla v každé oblasti, ale na druhé straně žádná nezaostává ve všech. Jinými slovy, to, jak úspěšná je určitá země v integraci přistěhovalců a jejich dětí, závisí na konkrétní oblasti nebo institucionálním kontextu, na něž se zaměříme.

Článek zkoumá široký rejstřík oblastí, počínaje náboženstvím a rasou. Pokračuje pracovním trhem, bydlením, vzděláním, smíšenými manželstvími a národností. Tak např́iklad pokud jde o náboženství, Spojené státy americké jsou při integrování přistěhovalců a jejich dětí, konkrétně máme-li na zřeteli islám, úspěšnější než západní Evropa. Spojené státy americké jsou též relativně úspěšné v oblasti vytváření nové identity: americká identita se totiž utváŕí zpusobem, jenž je vstřícnější vůči přistěhovalcům, a především jejich dětem z druhé generace, ve srovnání se státy západní Evropy. Ale pokud jde o rasu, s původem afrického černocha se pojí více překážek pro přistěhovalce a jejich děti v USA než v Evropě. Navíc se zdá, že nevýhody spojené s bydlením v přistěhovaleckých čtvrtích jsou mnohem závažnější v USA.

Při zkoumání nerovnosti u vzdělání analýza ukazuje, že žádný druh vzdělávací soustavy nezajištuje plnohodnotnou rovnost ve vzdělání u dětí z druhé generace se starousedlíky. Navíc určité prvky, jako např́klad velice složité soustavy, kde je zvykem učinit rozhodnutí velmi brzy, jako např. v Německu, plodí pro žáky s přistěhovaleckým původem značné nevýhody. Stejně je tomu tak u vysoce decentralizovaných školských soustav, jako např́lklad v USA. Pokud jde o pozitivnější aspekty, jsou u druhé generace stále běžnější smíšené svazky, třebaže v USA představuje rasa závažnou překážku při míšení u dětí černých přistěhovalcủ. V Evropě je však třeba upozornit na nízkou míru smíšených svazků s muslimy druhé generace, i když pozoruhodnou výjimkou je Francie.

Bez ohledu na danou oblast však analýza poukazuje na klíčovou roli historicky zakořeněných společenských, politických a ekonomických institucí v každé z přijímacích zemí, jež utvářejí u integrace a začlenění jak překážky, tak mosty, a mají tak při chápání vzorců integrace zásadní význam. Analýza také objasňuje, že velké univerzální ideje či to, čemu říkáme velkolepé příběhy - jako například integrační modely jednotlivých států, společnosti, kde se rozlišuje mezi osadníky a starousedlíky, představy o výjimečnosti USA nebo typologie z oblasti politické ekonomie o rozdílu mezi ekonomikou sociálního zabezpečení a volného trhu - neposkytují uspokojivá vysvětlení at již úspěchů nebo nezdarů při integraci v této pětici zemí. Závěrem článek předkládá úvahu o paradoxní povaze obrázku, jenž se rýsuje ve směsi integrace, nevyřešených problémů i překvapivého pokroku. 